Egyptian Journal of Rabbit Science, 29 (2): 235- 255(2019)

\title{
CROSSBREEDING EFFECTS AND POLYMORPHIC ASSOCIATIONS OF GENOTYPES OF GH GENE WITH GROWTH TRAITS IN RABBITS
}

\author{
A. R. Zaghloul ${ }^{1}$; Khalil, M.H. ${ }^{1}$; Iraqi, M. M. ${ }^{1}$; Ramadan, Sh. ${ }^{2}$ and EL \\ Nagar, A. G. ${ }^{1}$ \\ ${ }^{1}$ Department of Animal Production, Faculty of Agriculture, Benha University, \\ Egypt. \\ ${ }^{2}$ Department of Animal Wealth Development, Faculty of Veterinary Medicine, \\ Benha University, Egypt. \\ Corresponding author email: maher.khalil@fagr.bu.edu.eg
}

A simple crossbreeding experiment between two new synthetic rabbit lines (APRI and Moshtohor) was conducted to estimate the crossbreeding effects (direct additive, maternal additive and heterosis) on post-weaning body weights $(B W)$ at 4, 6, 8, 10 and 12 weeks of age and daily weight gains $(D G)$ during the intervals from 4 to 6,6 to 8,8 to 10 and 10 to 12 weeks, and to detect the polymorphic associations of the genotypes of GH gene with post-weaning body weight and daily gain traits. Four genetic groups of APRI (A-line), Moshtohor (M-line) and their simple $F_{1}$ cross $\left(1 / 2 A^{1 / 2 M}\right)$ in addition to $V$-line rabbits (as a reference population) were used in this study.

PCR-RFLP technique was applied using BstUI restriction enzyme SNP for genotyping the growth hormone gene (GH) (TT, TC and CC) genotypes. Heritabilities estimated by VCE program for body weights and daily weight gains were mostly low or moderate and ranging from 0.05 to 0.18. The percentages of direct additive effects on body weights were significantly $(P<0.01)$ in favour of Moshtohor line by 2.7, 4.3, 1.4, 2.6 and $2.9 \%$ at $4,6,8,10$ and 12 weeks and by 8.7, 15.9 and $18.6 \%$ in daily weight gains at DG4-6, DG6-8 and DG8-10, respectively. The percentages of maternal effects on body weights at 4, 6, 8, 10 and 12 weeks were also significantly in favour of Moshtohor line by 2.8, 5.4, 3.5, 3.5 and $3.1 \%$, respectively and ranged from 1.8 to $15 \%$ for daily weight gains in weight. The percentages of direct heterosis were significantly positive by 3.1, 8.1, 8.2, 5.2 and $3.8 \%$ for body weights at 4, 6, 8, 10 and 12 weeks and by 13.0, 7.8 and 9.6\% for daily weight gains at DG6-8, DG8-10 and DG10-12, respectively. The associations of the genotypes of GH gene were polymorphic and had significant effects on most growth traits $(P<0.05)$. There were significant differences $(P<0.05)$ between the 
generalized least square means of the different genotypes (TT, CC and TC) of GH gene for body weights at 4, 6, 8, 10 and 12 weeks of age in $V$ line, M-line, A-line and $1 / 2 A^{1 / 2} M$ cross rabbits. The TC genotype was positively associated with an increase in body weights of V-line, M-line and A-line rabbits, while the TT genotype indicated an increase in body weights of $1 / 2 A^{1 / 2 M}$ rabbits. The significant associations between $G H$ gene and growth traits confirmed that this gene could be a candidate gene and may be used in Marker-assisted selection (MAS) to improve growth performance in rabbits.

Conclusively, GH gene could be used as a candidate gene in genetic improvement programs to improve growth performance in rabbits.

Keywords: Rabbits, Growth, Crossbreeding effects, Genotyping, $G H$ gene, PCR-RFLP.

Crossbreeding is usually used to improve the overall production efficiency by using some breeds which have high genetic merit for different economic traits. In crossbreeding experiments performed in rabbits, most of the Egyptian and non-Egyptian studies (e.g. Piles et al., 2004; Abou Khadiga et al., 2008; Iraqi et al., 2008; Youssef et al., 2009; Khalil and Al-Homidan., 2014) showed significant direct additive and maternal genetic effects along with significant heterotic effects on body weights and gains at different ages. Until now, few studies have surveyed candidate genes for reproduction and growth traits in rabbits (Peiro et al., 2008a; Merchan et al., 2009; Garcia et al., 2010).

The candidate genes have successful approaches in identifying several DNA markers associated with production traits in rabbits. There were significant associations between the genotypes SNP and body weights. In this concept, the growth hormone gene $(G H)$ located on chromosome 19, growth hormone receptor gene $(G H R)$ located on chromosome 11, progesterone receptor gene $(P G R)$ located on chromosome 1, fibroblast growth factor gene $(F G F)$ located on chromosome 3, insulin-like growth factor 1 and 2 genes (IGFland IGF2) located on chromosome 4, myostatin gene (MSTN) located on chromosome 7 and melanocortin 4 receptor gene (MC4R) located on chromosome 9 have shown significant associations with body weighs in rabbits (Inoue et al., 2006; Fontanesi et al., 2008; Lu et al., 2011; Zhang et al., 2012; Fontanesi et al., 2012; Peng et al., 2013; Sahwan et al., 2014; Wu et al., 2015; Othman et al., 2015; El-Aksher et al., 2016; El-Sabrout and Aggag, 2017; Migdal et al., 2018). The growth hormone gene (GH) alters the metabolism of carbohydrates, proteins and lipids and promotes postnatal growth of mammals exerting direct or indirect effects on numerous tissues (Fontanesi et al., 2012). 
The technique of polymerase chain reaction (PCR) based on restriction fragment length polymorphism (PCR-RFLP) was recently used by Amalianingsih et al. (2014) and Hussein et al. (2015) for analysing single nucleotide polymorphisms (SNP) of the $G H$ gene in rabbits where a significant association between the SNP and marketing weight was detected. El-Sabrout and Aggag (2017) examined DNA parts of six growth genes: growth hormone $(\mathrm{GH})$, growth hormone receptor (GHR), melanocortin 4 receptor (MC4R), phosphorglycerate mutase (PGAM), myostatin (MSTN), and fibroblast growth factor (FGF) for two rabbit lines (V line and Alexandria) to investigate the associations between SNP of these genes and body weight at marketing. $G H$ gene mutations are described in several species, however, the studied concerning its variability and associations with economic traits in rabbits are scarce.

So, that aims of the current study were: (1) to estimate crossbreeding effects (i.e. direct additive, maternal additive and heterotic effects) on some growth traits in a crossbreeding experiment between APRI line (A) and Moshtohor line (M), and (2) to detect the associations between $(C>T)$ SNP genotypes of $\mathrm{GH}$ gene and growth traits in rabbits.

\section{MATERIALS AND METHODS}

\section{A crossbreeding experiment performed and animals used:}

A crossbreeding experiment between APRI line bucks (A) with Moshtohor line does (M) was carried out in the rabbitry of the Faculty of Agriculture, Benha University, Egypt to get $1 / 2 \mathrm{~A}^{1} / 2 \mathrm{M}$ cross. This experiment was conducted during the period from September 2015 until December 2017 to determine the crossbreeding effects on growth traits.

The animals used in this experiment were Moshtohor line, APRI line, $1 / 2 \mathrm{~A}^{1 / 2} \mathrm{M}$ and $\mathrm{V}$ line as a reference population. APRI line was developed in the Animal Production Research Institute, Ministry of Agricultures, Egypt (Youssef et al., 2009). The synthesis was conducted by crossing Red Baladi bucks (B) with $\mathrm{V}$ line does (V) followed by selection for litter weight at weaning in three subsequent generations and after F3, the animals were called APRI line consisting of $1 / 2 \mathrm{~V}^{1 / 2} \mathrm{~B}$. Moshtohor line was established in the Department of Animal Production, Faculty of Agricultures, Moshtohor, Benha University, Egypt (Iraqi et al., 2008). The synthesizing pattern of Moshtohor line was similar to that for APRI line, but with using Sinai Gabali bucks (S) instead of Red Baladi bucks. Consequently, this line is formed from $50 \%$ Sinai Gabali and $50 \% \mathrm{~V}$ line $\left(1 / 2 \mathrm{~S}^{1} / 2 \mathrm{~V}\right)$ where selection was practiced for litter weight at weaning and individual weight at $56 \mathrm{~d}$ and the animals were kept in the 
rabbitry of Benha University. The $\mathrm{V}$ line is a maternal line selected for litter size at weaning by Animal Science Department, Universidad Politécnica de Valencia, (UPV), Valencia, Spain. The interest of using line V lies in several features; first it has long history of selection in Valencia where the climate is not widely different from the weather of Delta of Nile in Egypt (Garcia and Baselga, 2002), second it has good performance in Saudi Arabia and had confirmed the fact that it has adaptable pattern in heat stress conditions (Khalil et al., 2005).

\section{Mating practiced:}

Mating was occurred at random within each genetic group, avoiding full and half sibs matings as well as parent offspring matings. The total number of weaned bunnies, sires and dams were 1201, 179 and 261, respectively (Table 1). Age of the does and bucks ranged between 4.5 and 5 months at first time of mating. Culled bucks and does or dead ones during the experimental period were replaced randomly by their replacements from the same line and from the original stock. The ratio of the experimental buck to does was 1:3 by using natural mating. Sire-daughter, full and half-sibs matings were avoided. Each doe was transferred to the assigned buck to be mated and returned back again to her own cage. On the day 10 post mating, each doe was palpated to detect pregnancy. Doe that was not pregnant would returned to the same mating buck to be re-mated and returned every other day thereafter until a service was observed. Likewise, does were re-mated after kindling by the same assigned buck.

Table 1: Number of animals, sires and dams categorized according to their genetic groups

\begin{tabular}{|l|c|c|c|c|c|}
\hline $\begin{array}{l}\text { Animal } \\
\text { genetic } \\
\text { group }\end{array}$ & $\begin{array}{c}\text { Buck } \\
\text { genetic } \\
\text { group }\end{array}$ & $\begin{array}{c}\text { Doe } \\
\text { genetic } \\
\text { group }\end{array}$ & $\begin{array}{c}\text { Number of } \\
\text { bunny } \\
\text { weaned }\end{array}$ & $\begin{array}{c}\text { Number } \\
\text { of sires } \\
\text { used }\end{array}$ & $\begin{array}{c}\text { Number of } \\
\text { dams used }\end{array}$ \\
\hline $\mathrm{V}$ & $\mathrm{V}$ & $\mathrm{V}$ & 439 & 60 & 90 \\
\hline $\mathrm{A}$ & $\mathrm{A}$ & $\mathrm{A}$ & 272 & 47 & 58 \\
\hline $\mathrm{M}$ & $\mathrm{M}$ & $\mathrm{M}$ & 312 & 48 & 73 \\
\hline $1 / 2 \mathrm{~A}^{1} / 2 \mathrm{M}$ & $\mathrm{A}$ & $\mathrm{M}$ & 178 & 24 & 40 \\
\hline Total & & & $\mathbf{1 2 0 1}$ & $\mathbf{1 7 9}$ & $\mathbf{2 6 1}$ \\
\hline
\end{tabular}

$\mathrm{V}=\mathrm{V}$ line, $\mathrm{A}=\mathrm{APRI}$ line, $\mathrm{M}=$ Moshtohor line.

\section{Housing and feeding:}

The rabbits were raised in one floor rabbitry, oriented east to west where windows and fans were oriented to control the ventilation. The rabbitry was 
equipped with regular electric heaters in winter to keep the minimum degree of temperature at $15^{\circ} \mathrm{C}$. In summer, there are fans and forced air-cooling to keep the maximum temperature at $35^{\circ} \mathrm{C}$. Breeding bucks and does were housed individually in wired cages with standard dimensions $(60 \times 40 \times 35 \mathrm{~cm}$ of length $\mathrm{x}$ width $\mathrm{x}$ height) and arranged in flat deck batteries. In the rabbitry, temperature ranged from 12 to $19^{\circ} \mathrm{C}$ in winter with the relative humidity ranged from 40 to $80 \%$ and photoperiod was at $16 \mathrm{~L}: 8 \mathrm{D}$. Each maternity cage was supplied with a galvanized steel nest boxes. Cages and nest boxes were cleaned and disinfected regularly after each kindling and urine and feces were cleaned every day morning. On the $25^{\text {th }}$ day of pregnancy, the nest boxes were supplied with thick layer of rice straw, which was placed in the bottom of the nest box to help the doe in preparing a warm comfortable nest for her bunnies. Litters were examined and counted within 12 hours after kindling and were checked and examined every morning during the suckling period to remove the dead bunnies. The bunnies were weaned, sexed, ear tagged, and transferred to standard progeny wire cages at 28 days post kindling.

The breeding animals were fed ad libitum all over the experimental period on a pelleted commercial ration; pellets were cylindrical in form $(1-2 \mathrm{~cm}$ in length and $0.4 \mathrm{~cm}$ in diameter). The ration was composed of $23 \%$ barley, 19 $\%$ wheat bran, $24 \%$ soybean meal , $21 \%$ berseem hay , $13 \%$ yellow corn , 1 $\%$ limestone, $0.5 \%$ table salt, $14 \mathrm{~kg}$ di-calcium phosphate/ton, $1 \mathrm{~kg}$ minerals mixture/ton, $1 \mathrm{~kg}$ anti-coccidian/ton, $1 \mathrm{~kg}$ anti-toxicity/ton, provided $18.01 \%$ crude protein, $13.7 \%$ crude fiber and $2.5 \%$ fat (digestible energy $=2500$ to $2700 \mathrm{kc} / \mathrm{kg}$ feed). Berseem" trifolium alexandrinum" was provided in winter months to all breeding animals to increase milk production of rabbit does and improve livability. All the animals were kept in the same house and reared under the same environmental conditions in every stage of productivity. Fresh drinking water was available all the time.

\section{Data of growth traits:}

Data were recorded for individual rabbits body weights (BW) in four genetic groups (V line, APRI line, $\mathrm{M}$ line and $1 / 2 \mathrm{~A}^{1} / 2 \mathrm{M}$ cross) at $4,6,8,10$, and 12 weeks of age. Daily weight gains (DG) were calculated during the age intervals from 4-6, 6-8, 8-10 and 10-12 weeks of age.

\section{Statistical models for estimating the crossbreeding genetic effects:}

Data of body weights and daily weight gains were analyzed using the following multi-trait animal model:

$$
\mathbf{y}=\mathbf{X b}+\mathbf{Z}_{\mathbf{a}} \mathbf{u}_{\mathbf{a}}+\mathbf{e}
$$

Where $y=$ vector of the observed growth trait for the weaned rabbit; $b=$ vector of the fixed effects of genetic group of progeny (four levels, see Table 1), sex 
(males and females), year-season of birth (eight levels), parity (five levels) and litter size in which the animal was born (three levels); $\mathrm{X}$ and $\mathrm{Z}_{\mathrm{a}}$ are incidence matrices corresponding to fixed and random additive effects of the rabbit $\left(\mathrm{u}_{\mathrm{a}}\right)$, respectively; $\mathrm{e}=$ vector of random residual effects.

The variance components of random effects and heritabilities were estimated by software: VCE6 (Groeneveld et al., 2010). The variance components were used to solve the corresponding mixed model equations, obtaining solutions for the genetic group effects and their error variancecovariance matrix using the PEST software (Groeneveld, 2006). According to the theory of Dickerson (1992), the solutions of the crossbreeding genetic group effects were obtained using the procedure of Generalized Least Squares (GLS) and applying the following linear model:

$$
\mathbf{y}=\mathbf{X b}+\mathbf{e}, \operatorname{Var}(\mathbf{y})=\mathbf{V}
$$

Where: $\mathrm{y}=$ Vector of the estimated genetic groups solutions; $\mathrm{X}=$ Incidence matrix; $b=$ Vector of estimable crossbreeding genetic effects; $e=$ Vector of random error; $\mathrm{V}=$ Error variance-covariance matrix of $\mathrm{y}$.

The coefficients relating the genetic crossbreeding effects to the means of the genetic groups (Table 2) were estimated according to the model of Dickerson (1992) and using CBE software (Wolf, 1996). In the experiment of crossing APRI bucks with Moshtohor does, the crossbreeding parameters representing the differences between the genetic groups were estimated in terms of direct additive effects $\left(G^{I}=G_{A}^{I}-G_{M}^{I}\right)$, maternal additive effects $\left(G^{M}\right)$ and direct heterosis $\left(\mathrm{H}^{\mathrm{I}}\right)$. Thus, we have three parameters to be estimated (the vector called b-vector):

$$
\mathbf{b}=\left[\left(\mathbf{G}_{\mathbf{A}^{\mathbf{I}}}^{\mathbf{A}}-\mathbf{G}_{\mathbf{M}}^{\mathbf{I}}\right) \mathbf{G}^{\mathbf{M}} \mathbf{H}^{\mathbf{I}}\right]
$$

The solutions of $\mathbf{b}$ were calculated by the method of Generalized Least Squares (GLS) using the following equation:

$$
\hat{\mathbf{b}}=\left(\mathbf{X}^{\prime} \mathbf{V} \mathbf{X}\right)^{-1} \mathbf{X}^{\prime} \mathbf{V}^{-} \mathbf{y}
$$

Where: $\mathbf{X}$ was the matrix of coefficients of estimable crossbreeding effects, $\mathbf{V}^{-}$ $=$ Generalized error variance-covariance matrix, with the variance-covariance matrix of the estimate of $b$ being,

$$
\operatorname{Var} \hat{\mathbf{b}}=\left(\mathbf{X}^{\prime} \mathbf{V} \mathbf{X}\right)^{-\mathbf{1}}
$$

The matrix used to test the significance of the crossbreeding effects is presented in Table 2 .

\section{Molecular genetic analyses:}

\section{Blood sampling and DNA extraction:}

Two hundred and eleven rabbits belong to V line, APRI line, M line and $1 / 2 \mathrm{~A} 1 / 2 \mathrm{M}$ cross were used in molecular genetic analyses. The samples were taken from animals with the least relationship with avoiding full sibs to decrease the 
Table 2: Genetic groups of animals with their sires and dams and coefficients of the matrix relating the means of the genetic groups with crossbreeding effects

\begin{tabular}{|c|c|c|c|c|c|c|c|c|}
\hline \multicolumn{3}{|c|}{ Genetic group } & \multirow[t]{2}{*}{ "Mean } & \multicolumn{5}{|c|}{ Coefficients of the matrix } \\
\hline Animal & Sire & Dam & & $G_{A}^{P}$ & $\mathbf{G}_{M}^{P}$ & $\mathbf{G}_{A}^{M}$ & $G_{M}^{M}$ & $\mathbf{H}^{\mathbf{I}}$ \\
\hline A & $\mathrm{A}$ & $\mathrm{A}$ & 1 & 1 & 0 & 1 & 0 & 0 \\
\hline $\mathbf{M}$ & $M$ & $\mathrm{M}$ & 1 & 0 & 1 & 0 & 1 & 0 \\
\hline $1 / 2 \mathbf{A}^{1} / 2 \mathbf{M}$ & A & $\mathrm{M}$ & 1 & 0.5 & 0.5 & 0.5 & 0.5 & 1 \\
\hline
\end{tabular}

$\mathrm{G}_{\mathrm{A}}^{\mathrm{P}}$ and $\mathrm{G}_{\mathrm{M}}^{\mathrm{P}}=$ Direct additive genetic effects for APRI and Moshtohor lines, respectively; $\mathrm{G}_{\mathrm{A}}^{\mathrm{M}}$ and $\mathrm{G}^{\mathrm{M}}{ }_{\mathrm{M}}=$ Maternal genetic effects for the APRI and Moshtohor lines, respectively; $\mathrm{H}^{\mathrm{I}}=$ Direct heterosis.

genetic relationships between the genotyped animals. Approximately 3-5 ml venous blood sample per animal was obtained from the rabbit ear vein by 2gauge 1.5-injection needle into tubes containing EDTA as anticoagulant. The blood samples were preserved in ice tank till reaching the laboratory and were then kept in freezer at $-20{ }^{\circ} \mathrm{C}$. Genomic DNA was extracted from leukocytes using the Gene Jet Whole Blood Genomic DNA purity Mini Kit (Cat No. \#K0781, Thermo Scientific).

\section{Amplification by polymerase chain reaction (PCR):}

PCR was done for amplification of part of the 5'untranslated region and part of exon 1 of the growth hormone gene $(G H)$ with expected amplicon size of $231 \mathrm{bp}$. According to Fontanesi et al. (2012), the primers used in the amplification were: the forward primer 5'- GTATAGTGGGATGGGGTTGG $3^{\prime}$ and the reverse primer 5'- TTACGCTCCCATTCAGAAGC -3 (Table 3). PCR amplifications were carried out in $50 \mu l$ reaction mixture composed of 4 $\mu l$ genomic DNA $(100 \mathrm{ng} / \mu l)$ as a template, 10 pmol of each primer, $2 \mathrm{mM}$ dNTP' (dATP, dCTP, dTTP and dGTP; ABgene, Surrey, UK), 10X PCR buffer, $25 \mathrm{mM} \mathrm{MgCl}$, and 1 unit Taq DNA polymerase. A master mix was prepared in a $2 \mathrm{ml}$ tube according to the number of PCR reactions to be performed, with an extra reaction included to compensate the loss part of the solution due to frequent pipetting. An aliquot of $46 \mu \mathrm{l}$ master mix solution was dispensed in each PCR tube $(0.2 \mathrm{ml}$ tube), containing $4 \mu l$ of the appropriate template DNA. Accordingly, the PCR reaction components are presented.

Thermal cycling was carried out by initial denaturation at $95^{\circ} \mathrm{C}$ for $5 \mathrm{~min}$, followed by 35 cycles each at $95^{\circ} \mathrm{C}$ for 30 seconds, annealing temperature at $58^{\circ} \mathrm{C}$ for 30 seconds, extension temperature at $72^{\circ} \mathrm{C}$ for 30 seconds and final extension at $72^{\circ} \mathrm{C}$ for $10 \mathrm{~min}$., then the samples were held at $4^{\circ} \mathrm{C}$. 
Table 3: Primer sequence and PCR-RFLP assay conditions for genotyping SNP of $G H$ gene

\begin{tabular}{|l|l|l|l|l|l|}
\hline $\begin{array}{l}\text { Gene(Gene } \\
\text { Bank } \\
\begin{array}{l}\text { Accession } \\
\text { no.) }\end{array}\end{array}$ & Location & Primer sequences (forward/reverse) & $\begin{array}{l}\text { PCR } \\
\text { Product } \\
\text { size (bp) }\end{array}$ & $\begin{array}{l}\text { Annealing } \\
\text { temp } \\
\text { time }\left({ }^{\circ} \mathbf{c} / \mathbf{s}\right)^{\mathbf{t}}\end{array}$ & $\begin{array}{l}\text { Restriction } \\
\text { Enzyme }\end{array}$ \\
\hline GH & $\begin{array}{l}\text { Chromosome 19, } \\
\text { NC_013687.1 }\end{array}$ & $\begin{array}{l}\text { 5'-GTATAGTGGGATGGGGTTGG-3' } \\
\text { 5'-TTACGCTCCCATTCAGAAGC-3'. }\end{array}$ & 231 & $58 / 30$ & BstUI \\
\hline
\end{tabular}

${ }^{\mathrm{a}} \mathrm{PCR}$ annealing temperature and time for primer.

The amplified DNA fragments were separated on $2 \%$ agarose gel, stained with ethidium bromide, visualized on a UV Transilluminator and photographed by gel documentation system (Alpha Imager M1220, Documentation and Analysis, System, Canada).

\section{Genotyping of GH gene using PCR-RFLP technique:}

The c.-78C $>$ T SNP of the growth hormone gene (Fontanesi et al. 2012) was genotyped by PCR-RFLP using Bsh1236I (BstUI) restriction enzyme (Fermentas, Vilnius, Lithuania). The RFLP technique was carried out in reaction volume $20 \mu \mathrm{l}$ consisted of: $7 \mu \mathrm{l}$ H2O, $2 \mu \mathrm{l}$ buffer, $10 \mu \mathrm{l}$ PCR product and $1 \mu \mathrm{l}$ restriction enzyme. Digested fragments were visualized by electrophoresis on 3 $\%$ agarose gel stained with ethidium bromide at $100 \mathrm{~V}$ in $1 \mathrm{x}$ TAE and visualized on a UV Transilluminator and photographed by gel documentation system. The 50 bp DNA step ladder (Promega) was included in each run.

\section{Model for detecting the associations between genotypes of $\mathrm{GH}$ gene and growth traits:}

For the associations between the SNP genotypes of $G H$ gene and postweaning growth traits in each genetic group separately, the effects of genotype C/T SNP on different growth traits were estimated using PEST software (Groeneveld, 2006) and applying the same multi-traits animal model defined in Model 1 (in matrix notation) after adding the fixed effect of the $i^{t^{\text {th }}} \mathrm{C} / \mathrm{T}$ SNP genotype of $G H$ gene (three genotypes; TT, CC and TC). The method of Generalized Least Squares (GLS) was used to get the polymorphic associations between genotypes of $G H$ gene and growth traits.

\section{RESULTS AND DISCUSSION}

Actual means and variations:

Actual means, standard deviations (SD) and coefficients of variation (CV\%) for body weights at 4, 6, 8, 10 and 12 weeks of age and daily weight 
gains (DG) during the intervals from 4 to 6,6 to 8,8 to 10 and 10 to 12 weeks of age across all genetic groups were presented in Table 4 . The overall means of body weights were 490,780,1085, 1330 and $1670 \mathrm{~g}$ at 4, 6, 8, 10 and 12 weeks of age and daily weight gains were $20.5,21.8,18.2$ and $24.2 \mathrm{~g}$ at 4-6, 68, 8-10 and 10-12 weeks, respectively. Youssef et al. (2009) estimated that the average body weights at 4, 6, 8, 10 and 12 weeks of APRI line to be 501,740, 1028,1323 and 1651g and the daily weight gains were 17.0, 20.5, 20.9 and $23.2 \mathrm{~g}$ at 4-6, 6-8, 8-10 and 10-12 week, respectively.

Table 4: Actual means, standard deviations (SD), coefficients of variation $(\mathrm{CV})$, and ranges for growth traits across all genetic groups

\begin{tabular}{|l|c|c|c|c|c|c|}
\hline Trait & $\begin{array}{c}\text { Number of } \\
\text { records }\end{array}$ & Mean & SD & CV & Minimum & Maximum \\
\hline Body weights at: \\
\hline 4 weeks (g) & 1201 & 490 & 60.93 & 12 & 310 & 685 \\
\hline 6 weeks (g) & 1164 & 780 & 80.43 & 10 & 530 & 1010 \\
\hline 8 weeks (g) & 1116 & 1085 & 112.16 & 10 & 760 & 1350 \\
\hline 10 weeks (g) & 1058 & 1330 & 96.22 & 7 & 1000 & 1820 \\
\hline 12 weeks (g) & 984 & 1670 & 138.46 & 8 & 1230 & 2000 \\
\hline Daily gains at: & 1163 & 20.51 & 7.04 & 34 & 1.4 & 50 \\
\hline 4-6 weeks (g) & 1115 & 21.84 & 8.56 & 39 & 0.7 & 45.7 \\
\hline 6-8 weeks (g) & 1046 & 18.17 & 7.91 & 44 & 0.7 & 52.1 \\
\hline 8-10 weeks (g) & 979 & 24.16 & 9.20 & 38 & 0.7 & 57.1 \\
\hline 10-12weeks (g) &
\end{tabular}

The ranges between minimum and maximum values in body weights at 4, 6, 8, 10 and 12 weeks across all genetic groups of rabbits were high, being 310 to 685,530 to 1010,760 to 1350,1000 to 1820 and 1230 to $2000 \mathrm{~g}$, respectively and from 0.7 to $57.1 \mathrm{~g}$ for daily weight gains. The coefficients of variation for body weights were moderate, ranging from 7 to $12 \%$, while the coefficients for daily weight gains were high ranging from 34 to $44 \%$.

\section{Body weights and daily gains in different genetic groups:}

Least square means of body weights in $1 / 2 \mathrm{~A}^{1} / 2 \mathrm{M}$ cross were higher than APRI line and lower than Moshtohor line at 4, 6, 8, 10 and 12 weeks of age (Table 5). These averages were lower than those values obtained for line $\mathrm{V}$ reared in Spain (e.g. García et al. 2000). These averages of $1 \frac{1}{2} \mathrm{~A} 1 / 2 \mathrm{M}$ cross rabbits were higher than those of APRI line intensified in Egypt (Youssef et al., 2009). Moreover, body weight at 4,8 and 12 week of $1 / 2 \mathrm{~A} 1 / 2 \mathrm{M}$ cross rabbits were in agreement with Iraqi et al. (2008) who found that the average body weights at 4 , 8 and 12 weeks was 589, 1193 and 1676g in Moshtohor line rabbits. 
Table 5: Generalized least square means \pm standard errors for body weights (BW) and daily gains (DG) as affected by genetic groups

\begin{tabular}{|c|c|c|c|c|c|c|c|c|}
\hline \multirow{3}{*}{ Traits } & \multicolumn{8}{|c|}{ Genetic groups } \\
\hline & \multicolumn{2}{|c|}{ V Line } & \multicolumn{2}{|c|}{ M Line } & \multicolumn{2}{|c|}{ A Line } & \multicolumn{2}{|c|}{$1 / 2 \mathbf{A}^{1} / 2 \mathbf{M}$} \\
\hline & Mean & SE & Mean & SE & Mean & SE & Mean & SE \\
\hline \multicolumn{9}{|c|}{ Body weights at: } \\
\hline BW4 & $475^{\mathrm{d}}$ & 15.8 & $520^{\mathrm{a}}$ & 20.09 & $490^{c}$ & 18.81 & $505^{b}$ & 21.38 \\
\hline BW6 & $780^{b}$ & 29.6 & $800^{\mathrm{a}}$ & 27.28 & $755^{\mathrm{d}}$ & 25.73 & $775^{\mathrm{c}}$ & 29.17 \\
\hline BW8 & $1125^{\mathrm{a}}$ & 40.6 & $1085^{b}$ & 37.17 & $1040^{c}$ & 35.03 & $1050^{\mathrm{c}}$ & 40.15 \\
\hline BW10 & $1325^{b}$ & 89.6 & $1370^{\mathrm{a}}$ & 78.83 & $1310^{\mathrm{d}}$ & 74.03 & $1320^{c}$ & 85.8 \\
\hline BW12 & $1665^{b}$ & 52.6 & $1690^{\mathrm{a}}$ & 49.2 & $1655^{\mathrm{d}}$ & 46.4 & $1660^{c}$ & 52.4 \\
\hline \multicolumn{9}{|c|}{ Daily gains at: } \\
\hline DG4-6 & $22.1^{\mathrm{a}}$ & 0.91 & $20.2^{\mathrm{b}}$ & 1.36 & $18.9^{\mathrm{d}}$ & 0.94 & $19.5^{\mathrm{c}}$ & 1.05 \\
\hline DG6-8 & $24.1^{\mathrm{a}}$ & 1.17 & $20.8^{\mathrm{b}}$ & 1.18 & $20.5^{\mathrm{b}}$ & 1.21 & $20^{\mathrm{c}}$ & 1.35 \\
\hline DG8-10 & $15.4^{\mathrm{d}}$ & 1.12 & $20.2^{\mathrm{a}}$ & 1.13 & $19.4^{\mathrm{b}}$ & 1.16 & $18.9^{\mathrm{c}}$ & 1.29 \\
\hline DG10-12 & $23.9^{b}$ & 1.35 & $23.6^{\mathrm{C}}$ & 0.92 & $23.9^{b}$ & 1.4 & $24.9^{\mathrm{a}}$ & 1.56 \\
\hline
\end{tabular}

$\mathrm{A}=\mathrm{APRI}$ line, $\mathrm{M}=$ Moshtohor line, Means within row, not sharing any letter, are significantly different $(\mathrm{P}<0.05)$.

For daily body gains, the averages were mostly moderate and ranged from 15.4 to $24.9 \mathrm{~g}$ (Table 5). These results were in agreement with Iraqi et al. (2008) who recorded an average daily gain of Moshtohor line in Egypt to be 17.5 to $21.2 \mathrm{~g}$ /day. In Spain, V line rabbits were higher, being $36.5 \mathrm{~g} /$ day for daily gain between weaning and 8 weeks and $37.9 \mathrm{~g} /$ day between weaning and 9 weeks of age (Garcia et al., 2000). Youssef et al. (2009) reported that APRI line rabbits in Egypt were lower in average daily gain than those of crossed rabbits obtained here (17.0 to $23.2 \mathrm{~g} /$ day).

\section{Heritabilities $\left(\boldsymbol{h}^{2}\right)$ :}

Heritabilities for body weights and gains estimated by VCE6 software is presented in Table 6 . Heritabilities estimated by VCE program for body weights were mostly low or moderate and ranging from 0.06 to 0.18 , while the estimates for daily body gains ranged from 0.05 to 0.10 . The heritabilities obtained here for body weights and gains were nearly similar to those estimates obtained by some studies in Egypt (Youssef, 2004; Youssef et al., 2009), in Nigeria (Akanno and Ibe, 2005), and in Brazil (Ferraz and Eler, 1996). Published estimates of heritability for daily weight gains were higher than those obtained in this experiment (Piles et al., 2004). Khalil and Al- Homidan (2014) reported that the heritabilities were mostly moderate and ranged from 0.19 to 0.27 for body weights and from 0.18 to 0.34 for daily weight gains. 
Table 6: Estimates of heritability \pm standard errors (SE) for growth traits estimated by VCE6 softwares

\begin{tabular}{|l|c|c|l|c|c||}
\hline Trait & $\begin{array}{c}\text { Number } \\
\text { of records }\end{array}$ & $\begin{array}{c}\mathbf{( h}^{2} \pm \text { SE } \\
\text { estimated by } \\
\text { VCE6 })\end{array}$ & Trait & $\begin{array}{c}\text { Number } \\
\text { of } \\
\text { records }\end{array}$ & $\begin{array}{c}\mathbf{( h}^{2} \pm \text { SE } \\
\text { estimated } \\
\text { by VCE6 })\end{array}$ \\
\hline \multicolumn{7}{|l|}{ Body weights at: } & & Daily gains at: & \\
\hline 4 weeks & 1201 & $0.10 \pm 0.033$ & & & \\
\hline 6 weeks & 1164 & $0.18 \pm 0.035$ & 4-6 weeks & 1163 & $0.08 \pm 0.001$ \\
\hline 8 weeks & 1116 & $0.17 \pm 0.039$ & $\mathbf{6 - 8}$ weeks & 1115 & $0.10 \pm 0.002$ \\
\hline 10 weeks & 1058 & $0.06 \pm 0.037$ & $\mathbf{8 - 1 0}$ weeks & 1046 & $0.05 \pm 0.003$ \\
\hline 12 weeks & 984 & $0.08 \pm 0.043$ & $\mathbf{1 0 - 1 2}$ weeks & 979 & $0.07 \pm 0.002$ \\
\hline
\end{tabular}

VCE6= Variance Component Estimation.

Iraqi (2008) estimated the heritability to be $0.05,0.38$ and 0.20 for body weights at 4,8 and 12 weeks, respectively and 0.23 and 0.19 for daily weight gains at 4-8 and 8-12 weeks, respectively in Sinai Gabali rabbits.

\section{Crossbreeding analysis:}

Direct additive effects $\left(G^{I}\right)$ :

The generalized least square solutions of $\mathrm{G}^{\mathrm{I}}$ and their percentages for body weights and gains given in Table 7 showed that the estimable solutions of $\mathrm{G}^{\mathrm{I}}$ were significantly in favour of Moshtohor line rabbits by 13.5 to $48.1 \mathrm{~g}$ for body weights and 0.5 to $3.7 \mathrm{~g}$ for daily weight gains, with percentages ranging from 1.4 to $4.3 \%$ for body weights and 2.1 to $18.6 \%$ for daily weight gains $(\mathrm{P}<0.01)$. However, crossbreeding experiments carried out in Egypt indicated that direct additive effects on most post-weaning body weights and gains were significant (Khalil and Afifi, 1991; Youssef et al., 2009; Ibrahim et al., 2008). Khalil and Afifi (1991) reported significant estimates of $\mathrm{G}^{\mathrm{I}}$ for body weight at 12 weeks of age. Abdel-Ghany et al. (2000) noted that direct additive effects from crossing New Zealand White with Baladi Red or Baladi Black rabbits were consistently in favour of Baladi Red or Baladi Black for post-weaning body weights and gains. In crossing $\mathrm{V}$ line and Baladi Red rabbits, Youssef et al. (2009) found that the direct additive effects were in favour of V line rabbits reaching $15.0 \%$ at 4 weeks and $13.3 \%$ at 12 weeks and the effects for daily body gains were significant reaching $35.7 \%$ at the interval of 10-12 weeks. In crossing Saudi Gabali with V line rabbits, the direct additive effects were significantly in favour of $\mathrm{V}$ line and ranging from 2.7 to $8.1 \%$ for body weights and 3.8 to $13.1 \%$ for daily weight gains (Khalil and Al-Homidan, 2014). Likewise, Piles et al. (2004) in crossing C line and R line rabbits in Spain reported significant estimates of direct additive effects for body weights and 
Table 7: Generalized least square solutions and percentages of direct additive effects $\left(\mathrm{G}^{\mathrm{I}}=\mathrm{G}_{\mathrm{A}^{-}}^{\mathrm{I}} \mathrm{G}_{\mathrm{M}}^{\mathrm{I}}\right)$ and their standard errors (SE) for body weights and gains in crossing APRI and Moshtohor lines

\begin{tabular}{|l|c|c|c|c|c|c|c|c|c|}
\hline \multicolumn{4}{|c|}{$\mathbf{G}^{\mathbf{I}}$ for body weights (BW) } & \multicolumn{5}{|c|}{$\mathbf{G}^{\mathbf{I}}$ for daily gains (DG) } \\
\hline Trait & $\mathbf{N}$ & $\begin{array}{c}\mathbf{G}^{\mathbf{I}} \\
\text { solution } \\
\text { (units) }\end{array}$ & $\mathbf{S E}$ & $\begin{array}{c}\mathbf{G}^{\mathbf{I}} \text { as } \\
\boldsymbol{\%}^{+}\end{array}$ & Trait & $\mathbf{N}$ & $\begin{array}{c}\mathbf{G}^{\mathbf{I}} \\
\text { solution } \\
\text { (units) }\end{array}$ & $\mathbf{S E}$ & $\begin{array}{c}\mathbf{G}^{\mathbf{I}} \text { as } \\
\mathbf{\%}^{+}\end{array}$ \\
\hline BW4 & 762 & $-13.5^{* *}$ & 0.11 & -2.7 & & & & & \\
\hline BW6 & 729 & $-33.2^{* *}$ & 0.13 & -4.3 & DG4-6 & 762 & $-1.7^{* *}$ & 0.025 & -8.7 \\
\hline BW8 & 699 & $-14.8^{* *}$ & 0.16 & -1.4 & DG6-8 & 697 & $-3.3^{* *}$ & 0.029 & -15.9 \\
\hline BW10 & 672 & $-35.2^{* *}$ & 1.4 & -2.6 & DG8-10 & 611 & $-3.7^{* *}$ & 0.032 & -18.6 \\
\hline BW12 & 628 & $-48.1^{* *}$ & 1.2 & -2.9 & DG10-12 & 611 & $-0.5^{\text {NS }}$ & 0.033 & -2.1 \\
\hline
\end{tabular}

${ }^{+}$Percentage computed as [Estimate of $\mathrm{G}^{\mathrm{I}}$ in units / $(\mathrm{A}+\mathrm{M}) / 2$ ] x100

${ }^{++} \mathrm{NS}=$ non-significant, ${ }^{* *}=\mathrm{P} \leq 0.01$

gaily gains at 32- 60 days. Ouyed and Brun (2008) in crossing Californian with New Zealand White found that the estimates of $\mathrm{G}^{\mathrm{I}}$ were in favour of New Zealand White for 63-d body weight.

\section{Maternal additive effect $\left(G^{M}\right)$ :}

The solutions of maternal effects and their percentages for body weights and gains given in Table 8 showed that the estimable solutions of $\mathrm{G}^{\mathrm{M}}$ were significantly in favour of Moshtohor line by 14.2 to $51.8 \mathrm{~g}$ for body weights and 0.48 to $3.1 \mathrm{~g}$ for daily weight gains in weight, with percentages ranging from 2.8 to $5.4 \%$ for body weights and 1.8 to $15.0 \%$ for daily weight gains. Similarly, crossbreeding experiments carried out in Egypt indicated that maternal effects on most body weights and gains were significant (e.g. Abou Khadiga et al., 2008; Ibrahim et al., 2008; Iraqi et al., 2008; Hekil et al., 2011). Abd El-Ghany et al. (2000) reported that maternal additive effects on body weights and daily weight gains were significantly in preference of New Zealand White at all ages considered, While Abou Khadiga et al. (2008) found that maternal genetic effects were significantly in favor of $\mathrm{V}$ line dams for body weights at 8 and 12 weeks of age. Iraqi et al. (2008) found that Gabali breed was significantly superior in $\mathrm{G}^{\mathrm{M}}$ over $\mathrm{V}$ line $(\mathrm{P}<0.01)$ for body weights at 8 and 12 weeks of age and daily weight gains at intervals of 4-8 and 8-12 weeks of age.

\section{Direct Heterosis $\left(\boldsymbol{H}^{I}\right)$ :}

The generalized least square solutions of $\mathrm{H}^{\mathrm{I}}$ and their percentages for body weights and gains given in Table 9 indicated that the estimable solutions of direct heterosis were positive and highly significant and ranged from 15.5 to 
Table 8: Generalized least square solutions and percentages of maternal effects $\left(\mathrm{G}^{\mathrm{M}}=\mathrm{G}^{\mathrm{M}}{ }_{\mathrm{A}}-\mathrm{G}^{\mathrm{M}}{ }_{\mathrm{M}}\right)$ and their standard errors (SE) for body weights and gains in crossing APRI and Moshtohor lines

\begin{tabular}{|l|c|c|c|c|c|c|c|c|c|}
\hline \multicolumn{4}{|c|}{$\mathbf{G}^{\mathrm{M}}$ for body weights (BW) } & \multicolumn{5}{|c|}{$\mathbf{G}^{\mathrm{M}}$ for daily gains (DG) } \\
\hline Trait & $\mathbf{N}$ & $\begin{array}{c}\mathbf{G}^{\mathrm{M}} \\
\text { solution } \\
\text { (units) }\end{array}$ & $\mathbf{S E}$ & $\begin{array}{c}\mathbf{G}^{\mathrm{M}} \text { as } \\
\mathbf{\%}^{+}\end{array}$ & Trait & $\mathbf{N}$ & $\begin{array}{c}\mathbf{G}^{\mathbf{M}} \\
\text { solution } \\
\text { (units) }\end{array}$ & $\mathbf{S E}$ & $\begin{array}{c}\mathbf{G}^{\mathrm{M}} \text { as } \\
\mathbf{\%}^{+}\end{array}$ \\
\hline BW4 & 762 & $-14.2^{* *}$ & 0.09 & -2.8 & & & & & \\
\hline BW6 & 729 & $-42.4^{* *}$ & 0.11 & -5.4 & DG4-6 & 762 & $-1.02^{*}$ & 0.018 & -5.2 \\
\hline BW8 & 699 & $-37.2^{* *}$ & 0.13 & -3.5 & DG6-8 & 697 & $-3.1^{* *}$ & 0.024 & -15.0 \\
\hline BW10 & 672 & $-47.3^{* *}$ & 0.8 & -3.5 & DG8-10 & 611 & $-2.9^{* *}$ & 0.026 & -14.6 \\
\hline BW12 & 628 & $-51.8^{* *}$ & 1.01 & -3.1 & DG10-12 & 611 & $-0.48^{\mathrm{NS}}$ & 0.024 & -1.8 \\
\hline
\end{tabular}

${ }^{+}$Percentage computed as [Estimate of $\mathrm{G}^{\mathrm{M}}$ in units/ $(\mathrm{A}+\mathrm{M}) / 2$ ] $\mathrm{x} 100$

${ }^{++} \mathrm{NS}=$ Non-significant, ${ }^{*}=\mathrm{P} \leq 0.05$ and ${ }^{*} *=\mathrm{P} \leq 0.01$

Table 9: Generalized least square solutions and percentages of heterotic effects $\left(\mathrm{H}^{\mathrm{I}}=\mathrm{H}_{\mathrm{A}}^{\mathrm{I}}-\mathrm{H}_{\mathrm{M}}^{\mathrm{I}}\right)$ and their standard errors (SE) for body weights and gains in crossing APRI and Moshtohor lines

\begin{tabular}{|l|c|c|c|c|c|c|c|c|c|}
\hline \multicolumn{4}{|c|}{$\mathbf{H}^{\mathrm{I}}$ for body weights (BW) } & \multicolumn{5}{c|}{$\mathbf{H}^{\mathrm{I}}$ for daily gains (DG) } \\
\hline Trait & $\mathbf{N}$ & $\begin{array}{c}\mathbf{H}^{\mathrm{I}} \text { solution } \\
\text { (units) }\end{array}$ & $\mathbf{S E}$ & $\begin{array}{c}\mathbf{H}^{\mathrm{I}} \text { as } \\
\mathbf{\%}^{+}\end{array}$ & Trait & $\mathbf{N}$ & $\begin{array}{c}\mathbf{H}^{\mathrm{I}} \text { solution } \\
\text { (units) }\end{array}$ & $\mathbf{S E}$ & $\begin{array}{c}\mathbf{H}^{\mathrm{I}} \text { as } \\
\mathbf{\%}^{+}\end{array}$ \\
\hline BW4 & 762 & $15.5^{* *}$ & 0.16 & 3.1 & & & & & \\
\hline BW6 & 729 & $62.6^{* *}$ & 0.19 & 8.1 & $\mathbf{D G 4 - 6}$ & 762 & $0.2^{\mathrm{NS}}$ & 0.026 & 1.1 \\
\hline BW8 & 699 & $87.1^{* *}$ & 0.24 & 8.2 & $\mathbf{D G 6 - 8}$ & 697 & $2.7^{* *}$ & 0.044 & 13.0 \\
\hline BW10 & 672 & $70.5^{* *}$ & 1.3 & 5.2 & DG8-10 & 611 & $1.6^{*}$ & 0.005 & 7.8 \\
\hline BW12 & 628 & $63.9^{* *}$ & 2.1 & 3.8 & DG10-12 & 611 & $2.3^{* *}$ & 0.049 & 9.6 \\
\hline
\end{tabular}

${ }^{+}$Percentage computed as [Estimate of $\mathrm{H}^{\mathrm{I}}$ in units/ $(\mathrm{A}+\mathrm{M}) / 2$ ] $\times 100$

${ }^{++} \mathrm{NS}=$ non-significant, ${ }^{*}=\mathrm{P} \leq 0.05$ and ${ }^{*}=\mathrm{P} \leq 0.01$.

87.1g for body weights and from 0.2 to $2.7 \mathrm{~g}$ for body gains, with percentages ranging from 3.1 to $8.2 \%$ for body weights and 1.1 to $13.0 \%$ for daily weight gains. Afifi et al. (1994) found that heterosis percentages in crossing New Zealand White with Baladi rabbits in Egypt were positive and ranged from 2.7 to $9.5 \%$ for post-weaning body weights and daily weight gains. Iraqi et al. (2008) found that the estimates of heterosis were always significantly positive by $6.9,3.6$ and $5.4 \%$ for body weights at 4,8 and 12 weeks and 9.7 and $6.1 \%$ for daily weight gains at intervals of 4-8 and 8-12 weeks, respectively. Youssef et al. (2009) found that direct heterosis were positive and ranged from 4.9 to $16.7 \%$ for body weights and 14.4 to $29.5 \%$ for daily weight gains. Khalil and Al-Homidan (2014) reported that direct heterosis were significantly positive and ranged from 4.5 to $5.4 \%$ for body weights and from 6.6 to $9.6 \%$ for daily weight gains. 
Polymorphic associations between genotypes of GH gene and growth traits:

The generalized least square means for SNP genotypes of $G H$ gene in V line, $\mathrm{M}$ line, $\mathrm{A}$ line and $1 / 2 \mathrm{~A}^{1} / 2 \mathrm{M}$ cross have shown significant effects on most body weights and gains (Table 10). Similarly, several studies reported significnt associations between $\mathrm{GH}$ gene and body weights in rabbits (e.g. Fontanesi et al, 2008; Abdel-Kafy et al, 2016; El-Sabrout and Aggag, 2017).

In $\mathrm{V}$ line rabbits, $\mathrm{CC}$ genotype was absent and the association of TT and TC genotypes of $G H$ gene was significant $(\mathrm{P}<0.05)$, since TT genotype was heaver for body weight at 4 weeks than TC genotype (Table 10). However, TT genotype was lower than TC genotype for body weights at 6, 8, 10 and 12 weeks. The TC genotype was positively associated with an increase in body weights at 6, 8, 10 and 12 weeks of age by 32, 9, 57 and $108 \mathrm{~g}$, respectively. For daily gain, the CC genotype was absent and the TT genotype was lower than TC genotype and the difference between SNP genotypes of $G H$ gene were significant $(\mathrm{P}<0.05)$ for most body gains studied (Table 10). These data was in agreement with El-Aksher et al (2016) who found significant associations $(\mathrm{P}<0.05)$ between the genotypes SNPs of progesterone receptor gene $(P G R$ gene) and body weights for $\mathrm{V}$ line and Sinai Gabali rabbits, Also, El-Sabrout and Aggag (2017) found significant $(\mathrm{P}<0.05)$ associations between growth hormone, insulin-like growth factor 1 , myostatin, melanocortin 4 receptor, growth hormone receptor and phosphorglycerate mutase genes and body weights in $\mathrm{V}$ line and Alexandria rabbits.

In Moshtohor line rabbits, the differences among genotypes of $G H$ gene were significant $(\mathrm{P}<0.05)$ and the TC genotype was heavier in body weights at 4, 6, 8, 10 and 12 weeks than CC and TT genotypes (Table 10). The TC genotype was positively associated with an increase in body weights at $4,8,10$ and 12 weeks of age by 134, 119, 636 and 734g, respectively. The differences among genotypes of $G H$ gene in all daily weight gains were significant $(\mathrm{P}<0.05)$ and the TT genotype was lower in daily weight gains at 6-8, 8-10 and 10-12 weeks than CC and TC genotypes. The TT genotype was heavier in daily gain at 4-6 weeks than CC and TC genotypes. Lu et al. (2011) and Peng et al. (2013) reported significant association between myostatin gene (MSTN) and growth traits in different genetic groups of rabbits.

The differences between genotypes of $G H$ gene in APRI line rabbits were significant $(\mathrm{P}<0.05)$ and $\mathrm{CC}$ genotype was heavier in body weight at 4 and 10 weeks than TT and TC genotypes, while the TC genotype was heavier in body weights at 6,8 , and 12 weeks than $\mathrm{CC}$ and TT genotypes (Table 10). The TC genotype was positively associated with an increase in body weights at 6,8 and 12 weeks of age by 43, 61 and 305 g, respectively. Significant differences $(\mathrm{P}<0.05)$ were recorded between genotypes of $G H$ gene in daily 
Table 10: Generalized least square means and their standard errors (GLM \pm SE) for body weights (BW) and daily gains (DG) as affected by SNP genotypes of GH gene in each genetic group separately

\begin{tabular}{|c|c|c|c|c|c|c|c|c|}
\hline \multirow{3}{*}{ Trait } & \multirow{3}{*}{$\begin{array}{c}\text { Breed or } \\
\text { genetic group }\end{array}$} & \multirow{3}{*}{$\begin{array}{c}\text { Number of } \\
\text { records }\end{array}$} & \multicolumn{6}{|c|}{ Genotypes } \\
\hline & & & \multicolumn{2}{|c|}{ TT } & \multicolumn{2}{|c|}{$\mathrm{TC}$} & \multicolumn{2}{|c|}{$\mathrm{CC}$} \\
\hline & & & GLM & SE & GLM & SE & GLM & SE \\
\hline \multicolumn{9}{|c|}{ Body weights $(\mathrm{g})$ : } \\
\hline \multirow{4}{*}{ BW4 } & V line & 62 & $499^{\mathrm{a}}$ & 11.6 & $456^{b}$ & 12.9 & -- & - \\
\hline & M line & 46 & $450^{c}$ & 31.6 & $584^{\mathrm{a}}$ & 22.7 & $498^{b}$ & 30.8 \\
\hline & A line & 35 & $495^{\mathrm{a}}$ & 19.4 & $474^{\mathrm{b}}$ & 8.8 & $496^{\mathrm{a}}$ & 21.2 \\
\hline & $1 / 2 \mathbf{A}^{1 / 2} \mathbf{M}$ & 68 & $494^{\mathrm{a}}$ & 11.7 & $495^{\mathrm{a}}$ & 7.4 & -- & -- \\
\hline \multirow{4}{*}{ BW6 } & V line & 61 & $770^{b}$ & 19.9 & $802^{\mathrm{a}}$ & 21.5 & -- & - \\
\hline & M line & 46 & $795^{b}$ & 30.8 & $796^{b}$ & 22.3 & $827^{\mathrm{a}}$ & 30.2 \\
\hline & A line & 34 & $707^{b}$ & 26.2 & $737^{\mathrm{a}}$ & 10.9 & $694^{c}$ & 25. \\
\hline & $1 / 2 \mathbf{A}^{1 / 2 M}$ & 64 & $780^{\mathrm{a}}$ & 19.2 & $758^{\mathrm{b}}$ & 12.3 & -- & -- \\
\hline \multirow{4}{*}{ BW8 } & V line & 58 & $1143^{b}$ & 22.0 & $1152^{\mathrm{a}}$ & 23.9 & -- & - \\
\hline & M line & 46 & $1029^{c}$ & 43.4 & $1148^{\mathrm{a}}$ & 31.4 & $1098^{\mathrm{b}}$ & 42.7 \\
\hline & A line & 34 & $1093^{\mathrm{a}}$ & 70.6 & $1095^{\mathrm{a}}$ & 28.8 & $1034^{\mathrm{c}}$ & 69.8 \\
\hline & $1 / 2 \mathbf{A}^{1 / 2 M}$ & 60 & $1043^{\mathrm{a}}$ & 24.7 & $1037^{b}$ & 16.1 & -- & -- \\
\hline \multirow{4}{*}{ BW10 } & V line & 55 & $1297^{b}$ & 15.9 & $1354^{\mathrm{a}}$ & 16.9 & -- & -- \\
\hline & M line & 46 & $1071^{\mathrm{c}}$ & 189 & $1707^{\mathrm{a}}$ & 134 & $1288^{\mathrm{b}}$ & 164 \\
\hline & A line & 34 & $1361^{b}$ & 66.2 & $1271^{\mathrm{c}}$ & 27 & $1399^{\mathrm{a}}$ & 65.4 \\
\hline & $1 / 2 \mathbf{A}^{1 / 2} \mathbf{M}$ & 60 & $1349^{\mathrm{a}}$ & 26.9 & $1261^{\mathrm{b}}$ & 17.8 & -- & -- \\
\hline \multirow{4}{*}{ BW12 } & $\mathrm{V}$ line & 50 & $1696^{b}$ & 24.5 & $1804^{\mathrm{a}}$ & 24.5 & -- & -- \\
\hline & M line & 45 & $1240^{c}$ & 75 & $1974^{\mathrm{a}}$ & 52.1 & $1564^{\mathrm{b}}$ & 70.8 \\
\hline & A line & 29 & $1673^{b}$ & 94.8 & $1917^{\mathrm{a}}$ & 32.1 & $1612^{c}$ & 89.1 \\
\hline & $1 / 2 \mathbf{A}^{1} / 2 \mathbf{M}$ & 59 & $1686^{\mathrm{a}}$ & 31.7 & $1657^{\mathrm{b}}$ & 20.7 & -- & -- \\
\hline \multicolumn{9}{|c|}{ Daily gains (g): } \\
\hline \multirow{4}{*}{ DG4-6 } & V line & 61 & $18.8^{\mathrm{b}}$ & 1.29 & $25.3^{\mathrm{a}}$ & 1.35 & -- & -- \\
\hline & M line & 46 & $24.6^{\mathrm{a}}$ & 2.9 & $15.1^{\mathrm{c}}$ & 2.05 & $23.5^{b}$ & 2.5 \\
\hline & A line & 34 & $14.7^{\mathrm{b}}$ & 1.65 & $18.6^{\mathrm{a}}$ & 0.71 & $14.1^{\mathrm{b}}$ & 1.42 \\
\hline & $1 / 2 \mathbf{A}^{1 / 2} \mathbf{M}$ & 64 & $20.3^{\mathrm{a}}$ & 1.36 & $18.9^{b}$ & 0.94 & -- & -- \\
\hline \multirow{4}{*}{ DG6-8 } & V line & 58 & $28.2^{\mathrm{a}}$ & 1.55 & $20.4^{b}$ & 1.63 & -- & - \\
\hline & M line & 46 & $16.7^{\mathrm{c}}$ & 3.6 & $25.1^{\mathrm{a}}$ & 2.5 & $19.3^{\mathrm{b}}$ & 3.1 \\
\hline & A line & 34 & $27.3^{\mathrm{a}}$ & 4.64 & $20.1^{b}$ & 2.02 & $18.8^{\mathrm{c}}$ & 4.04 \\
\hline & $1 / 2 \mathbf{A}^{1 / 2 M}$ & 60 & $18.9^{\mathrm{b}}$ & 1.62 & $20.2^{\mathrm{a}}$ & 1.10 & -- & - \\
\hline \multirow{4}{*}{ DG8-10 } & V line & 55 & $9.3^{b}$ & 1.27 & $20.7^{\mathrm{a}}$ & 1.37 & -- & -- \\
\hline & M line & 46 & $22.2^{\mathrm{b}}$ & 13.4 & $11.3^{\mathrm{c}}$ & 10.4 & $32.8^{\mathrm{a}}$ & 12.4 \\
\hline & A line & 34 & $19.3^{\mathrm{b}}$ & 2.79 & $18.1^{\mathrm{c}}$ & 1.21 & $31.4^{\mathrm{a}}$ & 2.42 \\
\hline & $1 / 2 \mathbf{A}^{1} / 2 \mathbf{M}$ & 60 & $16.8^{\mathrm{b}}$ & 1.62 & $22.1^{\mathrm{a}}$ & 1.09 & -- & - \\
\hline \multirow{4}{*}{ DG10-12 } & V line & 50 & $29.6^{\mathrm{a}}$ & 1.43 & $21.3^{b}$ & 1.40 & -- & -- \\
\hline & M line & 45 & $19.3^{\mathrm{c}}$ & 3.02 & $25.5^{\mathrm{b}}$ & 2.23 & $26.9^{\mathrm{a}}$ & 2.80 \\
\hline & A line & 29 & $22.6^{\mathrm{c}}$ & 5.52 & $24.0^{b}$ & 1.95 & $34.9^{\mathrm{a}}$ & 4.51 \\
\hline & $1 / 2 \mathbf{A}^{1 / 2 M}$ & 59 & $31.1^{\mathrm{a}}$ & 1.82 & $22.5^{\mathrm{b}}$ & 1.25 & -- & -- \\
\hline
\end{tabular}

$G H=$ Growth hormone gene; A=APRI line, $\mathrm{M}=$ Moshtohor line; letters in the same row indicate significant differences at $P<0.05$. 
weight gains at 6-8 and 10-12 weeks in APRI line. In China, Zhang et al. (2012) found significant associations $(\mathrm{P}<0.05)$ between growth hormone receptor gene $(G H R)$ and body weights in Tianfu Black, Ira and Champagne rabbits. Additionally, Wu et al (2015) reported significant association $(\mathrm{P}<0.05)$ between phosphorglycerate mutase gene (PGAM2) and growth traits in the same Chinese rabbit breeds.

The differences between genotypes of $G H$ gene in $1 / 2 \mathrm{~A}^{1} / 2 \mathrm{M}$ cross rabbits were significant $(\mathrm{P}<0.05)$ in all body weights except body weight at 4 weeks and the CC genotype was absent (Table 10). The TT genotype was heavier than TC genotype in all body weights and this TT genotype was positively associated with an increase of 22, 6, 88 and $29 \mathrm{~g}$ in body weights at 6, 8, 10 and 12 weeks of age, respectively. For body gains, the differences between genotypes of $G H$ gene in $1 / 2 \mathrm{~A} 1 / 2 \mathrm{M}$ rabbits were significant $(\mathrm{P}<0.05)$ and the TT genotype was heavier than TC genotype in all body gains, and the CC genotype was absent, while the TC genotype was higher than TT genotype at 8-10 weeks. Abdel-Kafy et al. (2016) studied the association between Myostatin (MSTN) gene and growth traits in APRI line and found that Allele $\mathrm{T}$ at the $\mathrm{c} .747+34 \mathrm{C}>\mathrm{T}$ SNP was significantly associated $(\mathrm{P}<0.05)$ with increased body weight at 12 weeks of age. Moreover, Othman et al. (2015) found that the genotypes of fibroblast growth factor 5 gene $(F G F-5)$ were associated significantly $(\mathrm{P}<0.05)$ with body weights in different populations of rabbits in Egypt.

\section{CONCLUSIONS}

* Crossing APRI line with Moshtohor line was associated with heterotic effects and could be beneficial to produce rabbits characterized by heavy body weights and gains.

* Based on direct and maternal effects, APRI line could be used as a siregroup and Moshtohor line as a dam-group in synthesizing new line of rabbits in Egypt to improve growth traits.

* The significant associations between $G H$ gene and growth traits confirmed that this gene could be was as a candidate gene and may be used as Markerassisted selection in genetic improvement programs (MAS) to improve growth performance in rabbits.

\section{ACKNOWLEDGMENTS}

The authors acknowledge the Central Laboratory of Faculty of Veterinary Medicine, Benha University for supporting the molecular analyses of this study through the research project entitled "Genetic improvement of local rabbit breeds by using molecular genetic techniques" financially supported by Scientific Research Fund of Benha University. 


\section{REFERENCES}

Abdel-Ghany, A., Ahmed, E. and Hassan, N. 2000. Crossbreeding genetic parameters of post-weaning growth traits of the Egyptian acclimatised New Zealand White and native Baladi Black rabbits. 7th World Rabbit Congress, Valencia, Spain, Volume A, 2000, 317-323.

Abdel-Kafy, E., Darwish, S. and Elkhishin, D. 2016. Correlating single nucleotide polymorphisms in the myostatin gene with performance traits in rabbit. World Rabbit Science, 24: 213-221.

Abou Khadiga, G., Saleh, K., Nofal, R. and Baselga, M. 2008. Genetic evaluation of growth traits in a crossbreeding experiment involving line $\mathrm{V}$ and Baladi Black rabbits in Egypt. $9^{\text {th }}$ World Rabbit Congress-June, 2008. Citeseer, 10$13,23-28$.

Afifi, E., Khalil, M., Khadr, A. F. and Youssef, Y. 1994. Heterosis, maternal and direct effects for postweaning growth traits and carcass performance in rabbit crosses. Journal of Animal Breeding and Genetics, 111, 138-147.

Akanno, E. and Ibe, S. 2005. Estimates of genetic parameters for growth traits of domestic rabbits in the humid tropics. Livestock Research for Rural Development, 17, 2005.

Amalianingsih, T., Brahmantiyo, B. and Jakariac, 2014. The Variability of growth hormone gene associated with ultrasound imaging of Longissimus dorsi muscle and perirenal fat in rabbits. Media Peternakan, 37: 1-7.

Dickerson, G. E. T. 1992. Manual for evaluation of breeds and crosses of domestic animals. Food and Agriculture Organization of the United Nations, Rome, 47.

El-Aksher, S. H., Sherif, H., Khalil, M., El-Garhy, H. A. and Ramadan, S. 2016. Polymorphism of progesterone receptor gene in Moshtohor line rabbits and their parental lines using PCR-RFLP technique. 3rd Inter. Conference on Biotechnology Applications in Agriculture (ICBAA), Benha University, Moshtohor and Sharm El-Sheikh, 5-9 April 2016, Egypt.

El-Sabrout, K. and Aggag, S. 2017. The gene expression of weaning age and its effect on productive performance of rabbits. World Rabbit Science, 25, 1-7.

Ferraz, J. B. S. and Eler, J. P. 1996. Comparison of animal models for estimation of (co) variance components and genetic parameters of reproductive, growth and slaughter traits of Californian and New Zealand White rabbits raised under tropical conditions. Proceedings of 6th World Rabbit Congress, 9-12 July 1996, Toulouse, France, 2: 279-284.

Fontanesi, L., Tazzoli, M., Scotti, E. and Russo, V. 2008. Analysis of candidate genes for meat production traits in domestic rabbit breeds. Proceedings of the 9th World Rabbit Congress, Verona, Italy, 10-13 June 2008, World Rabbit Science Association, 79-84. 
Fontanesi, L., Dall'olio, S., Spaccapaniccia, E., Scotti, E., Fornasini, D., Frabetti, A. and Russo, V. 2012. A single nucleotide polymorphism in the rabbit growth hormone (GH1) gene is associated with market weight in a commercial rabbit population. Livestock Science, 147:84-88.

García, M. and Baselga, M. 2002. Estimation of correlated response on growth traits to selection in litter size of rabbits using a cryopreserved control population and genetic trends. Livestock Production Science, 78: 91-98.

García, M., Baselga, M. and Peiró, R. 2000. Correlated response on growth traits in A line selected for litter size at weaning. Proceedings of 7th World Rabbit Congress, 4-7 July 2000, Valencia. Spain, A., 389-395.

García, M., Peiró, R., Argente, M., Merchán, M., Folch, J., Blasco, A. and Santacreu, M. 2010. Investigation of the oviductal glycoprotein 1 (OVGP1) gene associated with embryo survival and development in the rabbit. Journal of Animal Science, 88:1597-1602.

Groeneveld, E. 2006. PEST user's manual. Institute of Animal Husbandry and Animal Behaviour, Mariensee, Germany, FAL, Germany.

Groeneveld, E., Kovac, M. and Mielenz, N. 2010. VCE6 users manual. Federal Agricultural Research Centre (FAL), Neustadt, Germany.

Hekil, A. M., Gebriel, G., Enab, A., Hamoda, I. and Abdou, F. 2011. Genetic studies on some economic traits in rabbits. 2-Post-weaning body weight and growth rate. Egyptian Journal of Agriclture Research, 89: 345-360.

Hussein, B., Abdel-Kafy, E., Abdel-Ghany, S., Gamal, A. and Badawi, Y. 2015. Single nucleotide polymorphism in growth hormone gene are associated with some performance traits in rabbit. Int. J. Biol. Pharm. Allied Sci., 4: 490-504.

Ibrahim, M., Iraqi, M., Hassan, N. and El-Deghadi, A. 2008. Crossbreeding genetic effects for growth and livability traits in rabbits raised under hot climate conditions. Annals of Agric. Sci, Moshtohor, 45(3): 1091-1109.

Inoue, A., Takahashi, K. A., Arai, Y., Tonomura, H., Sakao, K., Saito, M., Fujioka, M., Fujiwara, H., Tabata, Y. and Kubo, T. 2006. The therapeutic effects of basic fibroblast growth factor contained in gelatin hydrogel microspheres on experimental osteoarthritis in the rabbit knee. Arthritis and Rheumatism: Official Journal of the American College of Rheumatology, 54, 264-270.

Iraqi, M. 2008. Estimation of genetic parameters for post-weaning growth traits of Gabali rabbits in Egypt. Livestock Research for Rural Development, 20, 2008.

Iraqi, M., Afifi, E., Baselga, M., Khalil, M. and García, M. 2008. Additive and heterotic components for post-weaning growth traits in a crossing project of $\mathrm{V}$ line with Gabali rabbits in Egypt. Proc. 9th World Rabbit Congress, Verona, Italy, 131-136.

Khalil, M.H. and Afifi E.A. 1991. Doe litter performance of Bouscat and Giza White rabbits. Egyptian J. of Rabbit Sci., 1(2): 172-184. 
Khalil, M. and Al-Homidan, A. 2014. Genetic evaluation for growth traits and thermo tolerance parameters in synthesizing program of new rabbits. $2^{\text {nd }}$ International Conference on Biotechnology Applications in Agriculture, Benha University, Moshtohor and Hurghada, 8- 11 April 2014, Egypt, 1-9.

Khalil, M., García, M., Al-Dobaib, S., Al-Homidan, A. and Baselga, M. 2005. Genetic evaluation of crossbreeding project involving Saudi and Spanish V line rabbits to synthesize new maternal lines in Saudi Arabia: I. Pre-weaning litter, lactation traits and feeding parameters. Proc. 4th International Conference on Rabbit Production in Hot Climates. 24-27 February 2005. Sharm El-Shiekh. Egypt.

Lu, J., Hou, S., Huang, W., Yu, J. and Wang, W. 2011. Polymorphisms in the myostatin gene and their association with growth and carcass traits in duck. African Journal of Biotechnology, 10:11309-11312.

Merchán, M., Peiró, R., Argente, M., Santacreu, M., García, M., Blasco, A. and Folch, J. 2009. Analysis of the oviductal glycoprotein 1 polymorphisms and their effects on components of litter size in rabbits. Anim. Genetics, 40: 756-758.

Migdal, L., Koziol, K., Palka, S., Migdal, W., Zabek, T., OtwinowskaMindur, A., Migdal, A., Kmiecik, M., Maj, D. and Bieniek, J. 2018. Mutations in leptin (LEP) gene are associated with carcass and meat quality traits in crossbreed rabbits. Animal Biotechnology, 29, 153-159.

Othman, O. E., Nowier, A. M., El-Kader, H., El-Aziem, S. H. A. and Youssef, Y. 2015. Genetic characterization of fibroblast growth factor-5 gene in rabbits. Global Veterinaria, 14:453-458.

Ouyed, A. and Brun, J. 2008. Heterosis, direct and maternal additive effects on rabbit growth and carcass characteristics. Proc.: 9th World Rabbit Congress, June 10-13, 2008 - Verona - Italy, 195-200.

Peiró, R., Merchan, M., Santacreu, M. A., Argente, M. J., García, M. L., Folch, J. M. and Blasco, A. 2008. Identification of single-nucleotide polymorphism in the progesterone receptor gene and its association with reproductive traits in rabbits. Genetics, 180: 1699-1705.

Peng, J., Zhang, G.-W., Zhang, W.-X., Liu, Y.-F., Yang, Y. and Lai, S.-J. 2013. Rapid genotyping of MSTN gene polymorphism using high-resolution melting for association study in rabbits. Asian-Australasian Journal of Animal Sciences, 26: 30-35.

Piles, M., Rafel, O., Ramon, J. and Gómez, E. 2004. Crossbreeding parameters of some productive traits in meat rabbits. World Rabbit Science, 12: 139-148.

Sahwan, F. M., El-Sheik, A. I., Sharaf, M. M. and El-Nahas, A. F. 2014. Genetic polymorphism in growth hormone receptor gene $(G H R)$ and its relationship with growth trait in pure and hybrid rabbit breeds. Alexandria Journal for Veterinary Sciences, 43, 45-51. 
Wu, Z., Chen, S., Jia, X. and Lai, S. 2015. Association of a synonymous mutation of the PGAM2 gene and growth traits in rabbits. Czech J. Anim. Sci, 60: 139-144.

Wolf, J. 1996. User's Manual for the Software Package CBE, Version 4.0 (A universal program for estimating crossbreeding effects). Research Institute of Animal Production, Prague-Uhrineves, Czech Republic.

Youssef, Y. 2004. Heritabilities and common litter effects estimated by an animal model for pot-weaning growth traits in New Zealand White and Baladi Red rabbits. Egyptian Poutltry Science, 24:205-216.

Youssef, Y., Baselga, M., Khalil, M., Omara, M. and García, M. 2009. Crossbreeding effects for post-weaning growth traits in a project of Spanish V line with Baladi Red Rabbits in Egypt. Livestock Science, 122: 302-307.

Zhang, W.-X., Zhang, G.-W., Peng, J. and Lai, S.-J. 2012. The polymorphism of GHR gene associated with the growth and carcass traits in three rabbit breeds. Proc. 10th World Rabbit Congr-September 3-6, 75- 78.

$$
\begin{aligned}
& \text { تأثيرات الخلطو وإرتباطات التنوع الجزيئي للتراكيب الوراثية لجين هرمون النمو مع } \\
& \text { صفات النمو في الأرانب } \\
& \text { عبد الفتاح راشد زغلول1، ماهر حسب النبي خليل، محمود مغربي عراقي'، }
\end{aligned}
$$

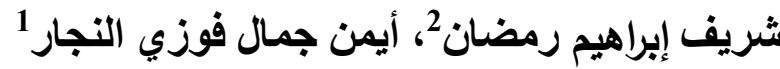

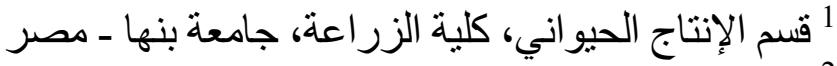

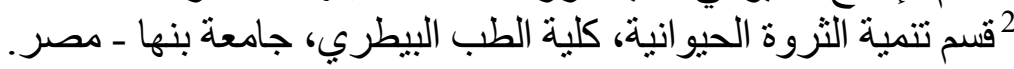

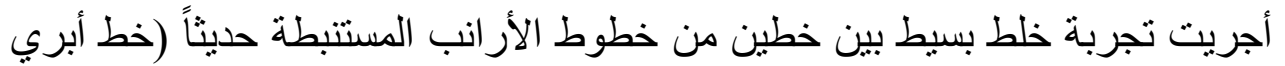
وخط مشتهر) بهدف تقدير نأثئرات الخلط (الأثر التجمعي المبانثر، الأثر الأمي المباثنر

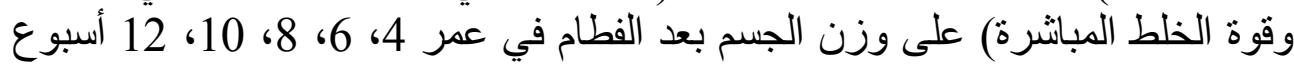

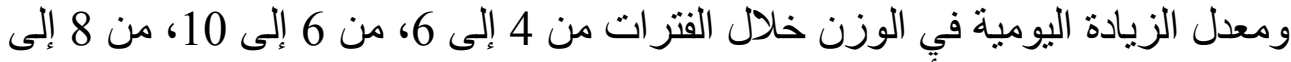

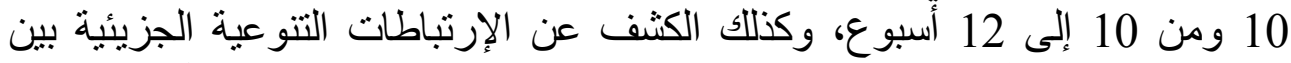

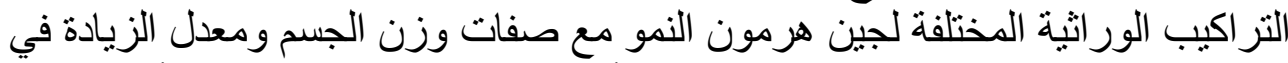

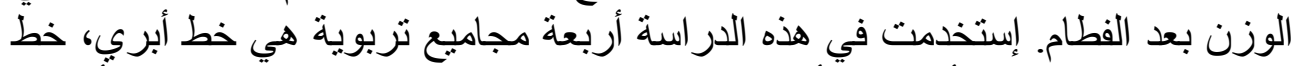

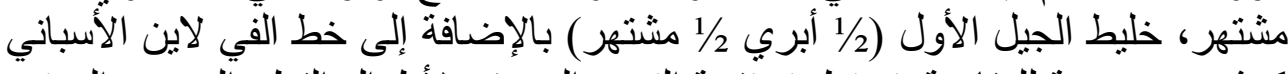

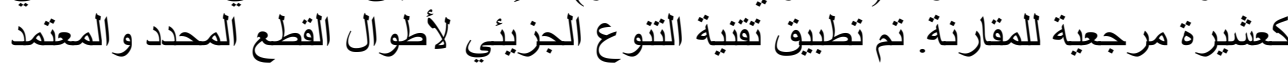

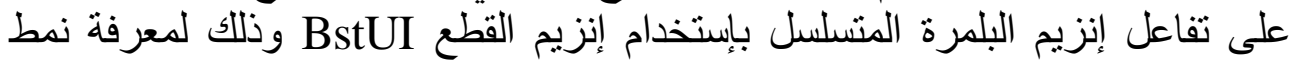
التنوع الجزيئي اللنيوكليوتيدة المفردة لجين هرمون النمو (TT, TC, CC). 
كانت النسب المئوية للأثر التجمعي المبانثر معنوية لصالح خط مشتهر 2.7 2.7، 4.3، 1.4،

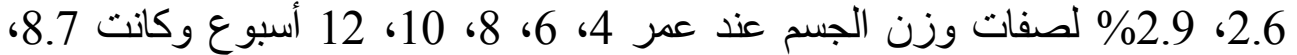

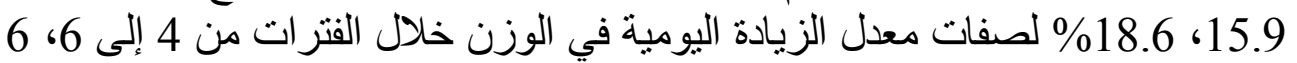

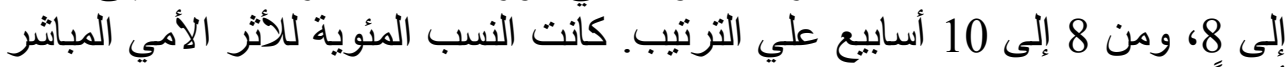

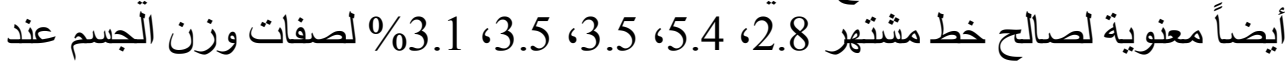

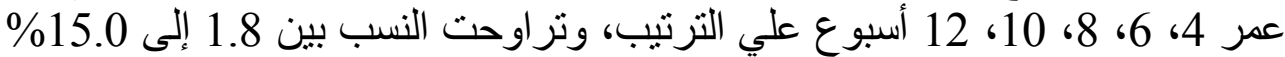

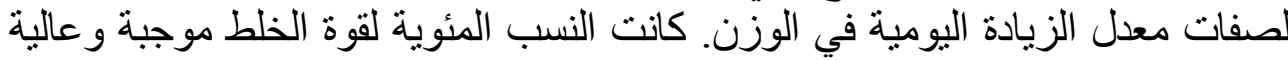

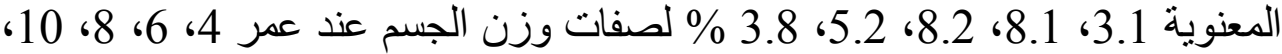

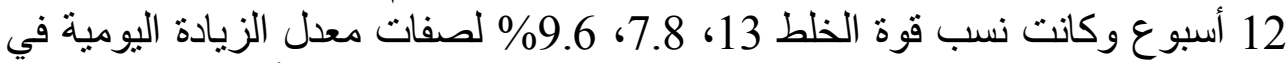

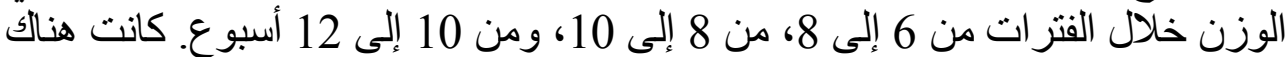

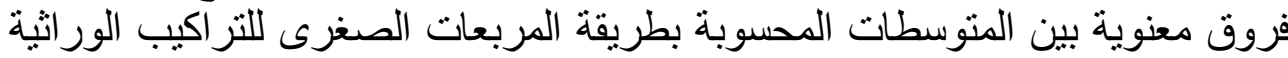

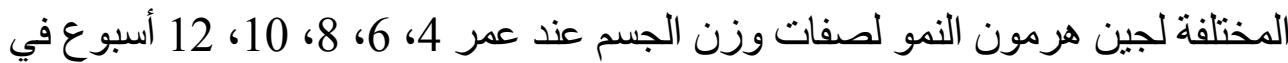

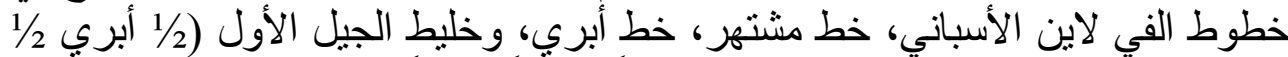

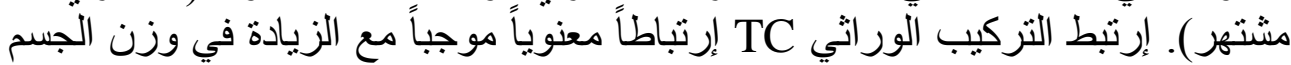

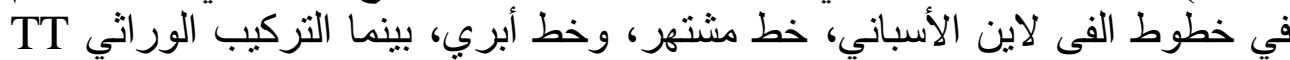

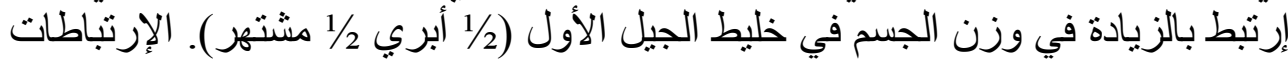

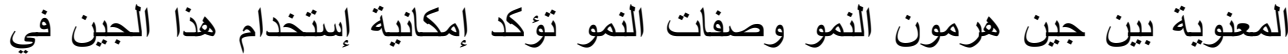
الإنتخاب بمساعدة الو اسمات لتحسين أداء النمو في الأر انب.

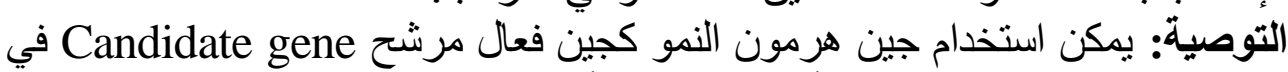
برامج التحسين الور اثي لتحسين أداء النمو في الأرانب. 